\author{
U.S. DEPARTMENT OF HEALTH AND HUMAN SERVICES \\ Centers for Disease Control \\ National Institute for Occupational Safety and Health \\ HEALTH HAZARD EVALUATION DETERMINATION REPORT \\ Report No. 82-000-004 \\ IDEAL CEMENT COMPANY \\ FLORENCE, COLORADO
}

I. SUMMARY

NOVEMBER , 1982

In November, 1980, the United Steelworkers of America Union, Local 14482, asked NIOSH to perform a general health hazard evaluation of the Ideal Cement Company, in Florence, Colorado. At that time, NIosh was already engaged in the nationwide morbidity study of randomly selected Portland Cement plants. Early in 1981, 36 workers from the Ideal plant served as a control group for a NIOSH medical study of a nearby uranium mill. (BETA 81-055-954 Sept 1981) No environmental evaluations were conducted at the plant in conjunction with the medical testing.

Following the results of the medical study there was renewed interest in a general health hazard evaluation. On March 22-23, 1982, industrial hygienists from NIOSH surveyed the facility to determine worker exposure to respirable and total dust, crystalline silica, toxic metals, aitrogen dioxide, and carbon monoxide.

Measurements of employee exposure to crystalfine silica and metals were found to be below recommended concentrations. Dusts throughout the plant may be irritating to the nose, throat, and upper airways, but there should be no serious damage to body tissue. No substances were found either in the plant atmosphere or community drinking water in concentrations toxic to kidneys.

KEY WORDS: Sic 3241 (Portland Cement) Nephrotoxins, respirable dust, total dust, toxic metals, crystalline silica, carbon monoxide, nitrogen dioxide.

\title{
II. BACKGROUND
}

The cement plant is located five miles from Florence, Colorado, along the Arkansas River. The original plant was built in 1900, but has since been dismantled. In 1948 a second plant with two kilns was built and remains in use today. In 1973 plant 3 , with one kiln, was built. Today, the overall facility is actually two separate plants, with autonomous kilns and mills. Across the river is the limestone quarry which serves as the calcium source for cement production.

The limestone is crushed at the quarry site by a primary rollermill and a secondary hamermill. Crushed limestone is carried to the plants by conveyor, where it is blended, mixed with water, and ground in ball wills into a fine slurry. Other raw materials, such as sand and iron ore, may be added during the milling process. The slurry is agitated 
and blended to the desired chemical and physical compositions and pumped into rotating kilns. The kilns progressively heat the slurry until temperatures of about $2700^{\circ} \mathrm{F}$ are reached at the fire end of the kiln. At this temperature the raw mix is fused forming "clinker minerals". The four chief clinker minerals are tri-calcium silicate $\left(3 \mathrm{CaO}-\mathrm{SiO}_{2}\right)$, dicalcium silicate $\left(2 \mathrm{CaO}-\mathrm{SiO}_{2}\right)$, tricalcium aluminate $\left(3 \mathrm{CaO}-\mathrm{Al}_{2} \mathrm{O}_{3}\right)$,

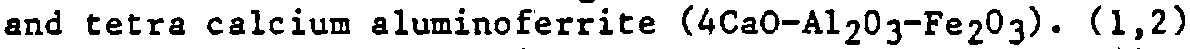
Gypsim is added to the clinkers and they are milled to increase the fineness and surface area. This ground powder is Portland cement. The cement is then either bagged or loaded as bulk in trucks or rail cars. Five types of cement are manufactured at this plant.

Coal is used as the fuel source for all three kilns. The coal is brought in by rail from mines in Colorado.

The Mine Safety and Health Administration (MSHA) has surveyed this plant and quarry on several occasions. Although the workers are exposed to crystalline silica, personal exposure levels have generally been below the federal dust standards.

\section{METHODS AND MATERIALS}

\section{General Comments and Schedule}

All respirable and total dust samples except those listed in Table 5, are personal samples and are therefore directly related to worker exposure. Personal and area samples were collected over the full 8-hour shift, and are therefore measurements of the average dust concentrations over the shift. The duties of many cement workers will vary from day to day and station to station. Also, there will be variations in atmospheric conditions such as wind speed and direction, and occurrence of precipitation. Because of this, personal samples collected only over two days may not accurately represent potential worker exposure to various toxicants. We elected, therefore, to primarily sample laborers, repairmen, and workers generally thought to encounter the highest dust exposures. This might indicate the worst case conditions for workers at Ideal Cement.

Al1 sampling equipment was calibrated in Florence the day before the survey began. Temperature and pressure corrections were applied to the volumes of collected air samples. Control filters were collected on site during the survey. These filters received treatment identical to dust laden filters, except no air was drawn through the control filters. During sampling periods, each personal and area sampler was periodically checked for proper operation. If the sampler was not operating properly, sampler adjustments and appropriate notations were made and, if necessary, the results of such samples were voided. 
The sampling schedule was as follows:

$\begin{array}{lll}\text { Monday, March 22 } & - & \text { lst shift } \\ \text { Tuesday, March } 23 \quad- & \text { lst shift }\end{array}$
follows:

Average atmospheric conditions for the sampling periods were as

$\begin{array}{lll} & \text { Monday } & \text { Tuesday } \\ \text { Barometric Pressure } & 633 \mathrm{mmHg} & 629 \mathrm{mmHg} \\ \text { Temperature } & 510 \mathrm{~F} & 570 \mathrm{~F} \\ \text { Relative Humidity } & 34 \% & 19 \% \\ \text { Precipitation } & 0 & 0 \\ \text { Wind Speed } & 50-100 \mathrm{fpm} & 5-850 \mathrm{fm}\end{array}$

These measurements were taken in the yard of the cement plant.

\section{Personal Respirable and Total Dust Samples}

Selected workers were requested to wear respirable or total dust sampling devices. To collect respirable dust, air was pulled through a $10 \mathrm{~mm}$ nylon cyclone and a polyvinyl chloride filter (PVC) at a flow rate of 1.7 liters per minute ( $\mathrm{lpm}$ ) by a personal sampling pump. At this flow rate, the cyclone separates the collected airborne dust into two fractions. Those particles considered to be non-respirable drop to the bottom of the cyclone and are discarded. The collection efficiency curve for this cyclone is presented in Figure 1. Particles greater than 10 micrometers $(\mu \mathrm{m})$ in aerodynamic diameter would not pass through the cyclone and be deposited on the filter, whereas almost all particles smaller than 1.5 micrometers in diameter would be collected on the filter. (3) The basic sampling apparatus for respirable dust, minus the cyclone size selector, is used to collect total airborne dust. Air is pulled through a PVC filter mounted in a polystyrene filter holder at a flow rate of $1.7 \mathrm{lpm}$. Those particles $20 \mathrm{Hm}$ and below are collected efficiently on the filter media. Those particles greater than 20 m generally fall through the air too rapidly to be captured on the filter $(4,5)$. The filters were weighed on a precision balance to the nearest 0.01 milligram (mg), before and after sampling. The weight gain of the filters, the sampling flow rates, and the sampling times were used to calculate time-weighted average airborne dust levels. Personal respirable dust levels are reported in Table 1 as milligrams per cubic meter. Included in the table are the geometric mean (GM) and geometric standard deviation (GSD) of the respirable dust data. Geometric values give a better estimate of the true population mean and standard deviation, because dust concentration data typically follow a log-rormal distribution. The geometric mean is the average of the logs of the dust concentrations and the geometric standard deviation is a measure of the variability of the data. The "Range" values are maximum and minimum observed values for the data. After weighing, 13 of the respirable filters were subjected to analysis by $x$-ray diffraction to determine their content of the crystalline silica polymorphs, quartz and cristobalite. (6) Quartz is also reported in Table 1 as milligram per cubic meter and percent quartz. A value of " $N$ " indicates that the 
Figure 1

COLLECTION EFFICIENCY OF THE PERSONAL RESPIRABLE DUST CYCLONE

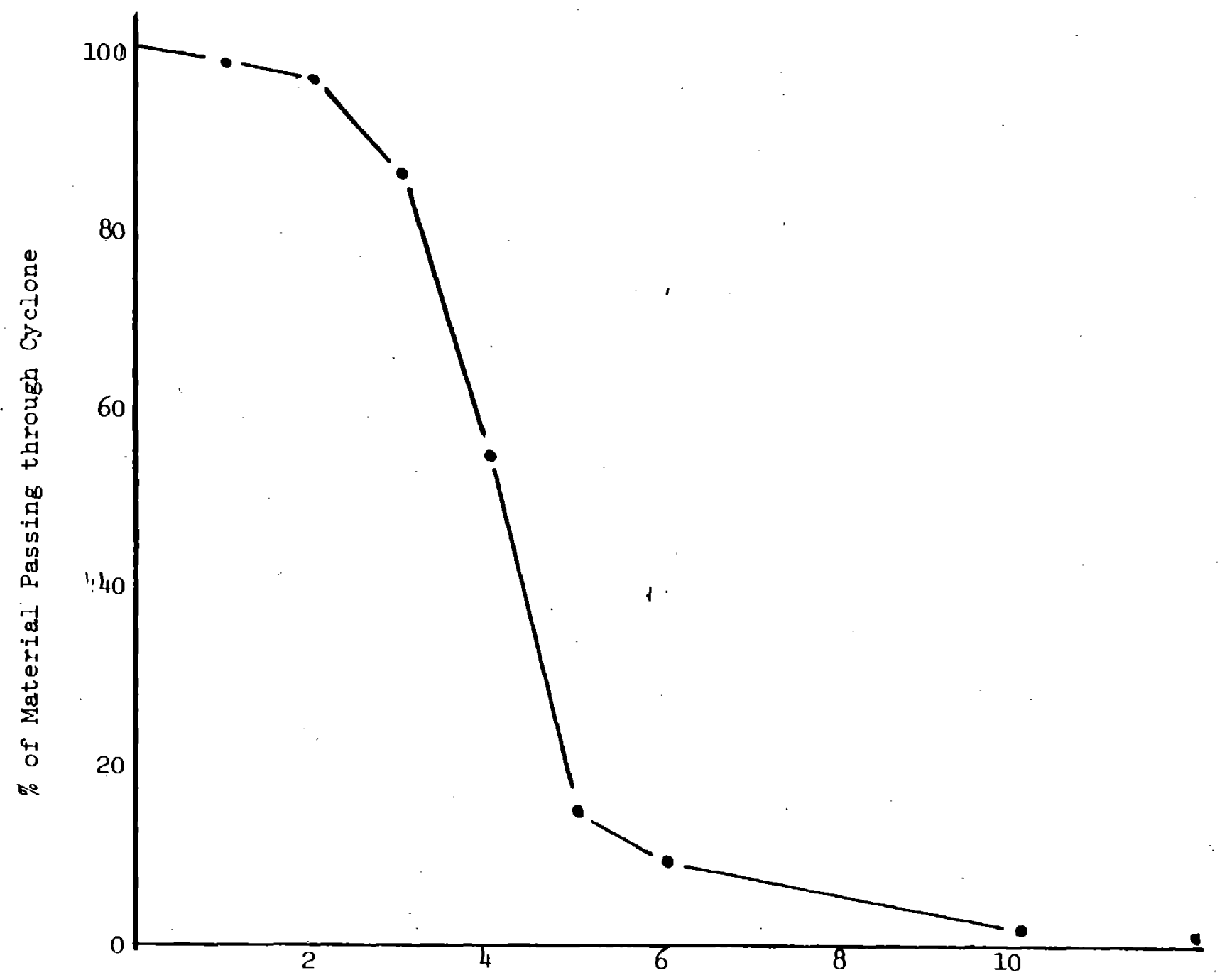

Particle Aerodynamic. Diameter in Micrometers (um) 
measured quantity was below the analytical limit of detection. Limit of detection for this method is $0.03 \mathrm{mg}$ per filter. No cristobalite was detected on any of the filters.

Total dust concentrations are listed and sumarized in Table 3 as milligrams per cubic meter $\left(\mathrm{mg} / \mathrm{m}^{3}\right)$.

Eight personal respirable and nineteen personal total dust samples were analyzed for content of 28 elements. These samples were ashed using nitric and perchloric acids and the residues dissolved in diluted nitric acid. The resulting solutions were analyzed for trace metal content by inductively coupled plasma - atomic emission spectroscopy (ICP-AES). (7) The results of the analyses for the respirable and total dust samples are reported in Tables 2 and 4 respectively, as milligrams per cubic meter $\left(\mathrm{mg} / \mathrm{m}^{3}\right)$. A value of " $N$ " indicates that the measured quantity was below the analytical limit of detection. For this analysis technique, the lower limit of detection is $0.001 \mathrm{mg} /$ filter for all elements.

\section{Area Respirable and Total Dust Samples}

Area respirable dust samples were collected in the packhouse and mill room of plant 2. These samples were analyzed for content of quartz and cristobalite. The results of the analyses are reported in Table 5. Samples were collected with a respirable dust cyclone identical to the ones used in personal sampling, and also with high volume respirable dust cyclones. High volume cyclones are designed to collect dust with similar collection efficiency as the personal cyclones when operated at flow rates of 10 liters per minute. At these higher flow rates, they collect more dust on their filters. By increasing the dust load, the sensitivity of quartz and cristobalite detection is increased. The dust concentrations on Table 5 , suggest that one high volume sampler tended to underestimate the respirable dust concentrations as measured by the personal cyclone, where the other tended to overestimate dust concentrations. An area total dust sample was collected in the mill room of plant 2 and analyzed for content of crystalline silica. (Table 5)

\section{Cascade Impactor Samples}

The Andersen Particle Fractionating Sampler was used to collect samples of airborne particles in the bagging area of the packhouse and the mill room of Plant 2. The Andersen sampler is a multi-stage, multi-orificed, cascade impactor which is used to measure the aerodynamic size distribution of airborne dust particles. After the air enters the impactor it cascades or flows successively through orifices with smaller and smaller diameters. The decrease in orifice size causes the velocity of the air stream to increase. This increase in air stream velocity results in successively smaller particles being inertially impacted on collection media. (8) Glass fiber filters were used as the collection media. No air is actually drawn through the filters; the particles are impacted or come to rest on the filters. These glass fiber filters are weighed to the nearest 0.1 milligram. Comparison of initial filter weights with final weights yields the weight of dust particles on each filter. These weights are used to calculate a 
cumulative weight percentage value for each stage. These cumulative weight percentages are plotted on log-probability graph paper against the corresponding effective cutoff diameters for each stage. From this graph the percentage of the mass of airborne particles below a particular aerodynamic diameter can be estimated.

Graphs of samples collected in the bagging area and mill room are presented in Figures 2 and 3 respectively. On the horizontal coordinate $c$ an be seen the percent (by weight) of the sample consisting of particles less than the aerodynamic diameter indicated on the corresponding vertical coordinate. For example, $15 \%$ of the dust mass in the bagging area are particles below $4 \mathrm{hm}$ in diameter. Two cascade impactor samples at different flow rates were taken in each location. The effective cutoff diameter is calculated for each impactor stage based on the flow rate. The effective cutoff diameters are the median particle diameter that will be collected on that stage.

\section{Bulk Material Samples}

Samples of raw material dust, clinker, finished product, and mixtures of dust were collected for analysis. These samples were generally collected from dust settled on ledges or objects several feet above the ground in the general work area. For this reason, it is suspected that these particles were at one time suspended in air before coming to rest. These bulk material samples cannot, however, be considered airborne samples. This material was analyzed for content of quartz and cristobalite by x-ray diffraction ( 6$)$; aluminum, chrominum, cobalt, magnesium, manganese, and nickel content by atomic absorbtion (12); and hexavalent chromium by extraction with hot sodium carbonate and sodium hydroxide solution and diphenylcarbazide colorimetry. (13)

The results of these analyses are presented in Table 6 . The "AREA" column indicates the work area from which samples were taken or type of dust. The results of analysis are presented as percent by weight of material. For example, if $1 \%$ of the raw material is quartz, there is 0.01 gram of quartz in each gram of raw material. The value " $N$ " indicates that the measured quantity was below the analytical limit of detection. The lower limits of detection are listed on Table 6 .

One to two liters of five different types of dust were collected and fractionated by a centripetal particle classifier. This classifier suspends the particles in an air stream and then separates them into coarse and fine fractions by centripetal force. The coarse fraction consisted of those particles greater than $20 \mathrm{Hm}$ in diameter, and the fine fraction those particles less than $20 \mathrm{Hm}$ in diameter. Theoretically, cut points between 20 and $30 \mathrm{fm}$ would divide the particles into those which are inhalable and those which fall through the air too rapidly to be inhaled during normal breathing.

Material collected from the fine portion of the bulk samples was mixed with 15 milliliters of water until a saturated water-particle mixture was produced. This mixture was then tested for hydrogen ion concentration by $\mathrm{pH}$ indicator sticks. The results are presented in Table 7 . 


\section{Nitrogen Dioxide $\left(\mathrm{NO}_{2}\right)$}

Nitrogen dioxide sampling was done using passive dosimeters. Al1 samples were personal. Full shift time-weighted average exposures were determined. Dosimeters were constructed by cutting lengths of acrylic tubing to give a length to area ratio of 10 to 1 . One end of the tube was fitted with a removable cap-plug and the other end was oealed with a cap containing the collection grids. These grids were coated with triethanolamine which quantitatively absorbs $\mathrm{NO}_{2}$. During exposure, the cap-plug is removed and the contaminant gas diffuses to the collection grid according to. Fick's Law of Diffusion. After collection, a sulfanilamide - phosphoric acid - NEDA solution is added to the dosimeter, where a red color complex with $\mathrm{NO}_{2}$ is formed. The solution is transferred to a spectrophotometer and the absorbitivity is measured at $540 \mathrm{um}$. This is compared against a standard curve to give nanomoles $\mathrm{NO}_{2}$, from which the concentration is calculated as: $(9,10)$

$$
\begin{gathered}
\text { concentration in parts per } \\
\text { million of air }
\end{gathered}=\frac{\text { (nanomoles }}{2.3 \times \text { (hours of exposure) }}
$$

The results of $\mathrm{NO}_{2}$ sampling are 1 isted in Table 8. Concentrations are presented in parts per million of air by volume.

\section{Carbon Monoxide}

Carbon monoxide was sampled by a portable direct reading analyzer. Air is drawn through an electrochemical voltametric sensor, passing over a gas diffusion-type-electrocatalytic sensing electrode. Some of the carbon monoxide molecules diffuse into, and are absorbed on the electrode, where they are electrochemically oxidized. This electrochemical reaction generates an electric current, directly proportional to the gas concentrations. The results of sampling are reported in Table 9 and read in parts per million of air (ppm). (11)

\section{Comonity Water Analysis}

Analyses of the drinking water for the city of Florence was obtained from the Colorado Department of Health. The water was analyzed for content of trace elements, pesticides, and herbicides. The concentration of all materials are below the lower limit of detection for that analysis technique, except fluoride. The results are 1 isted in Table 10. Following each material is the detected concentrations, the analytical lower limit of detection ( $N$ ), and the mandatory guidelines set by the Colorado Dept of Health.

IV. REVIEW OF LITERATURE AND EVALUATION CRITERIA

\section{Nuisance Dusts}

Portland Cement is presently considered to be "nuisance" dust. "Nuisance" particulates, by definition, generally have little adverse effect on lungs and do not produce significant organic disease or toxic effect when exposures are kept under reasonable control. Generally, the 
lung-tissue reaction caused by inhalation of nuisance dusts has the following characteristics:

1. The architecture of the air spaces remains intact.

2. Collagen (scar tissue) is not formed to a significant extent.

3. The tissue reaction is potentially reversible. (14)

The MSHA standard for an 8-hour time weighted average exposure to nuisance dusts is 10 milligrams per cubic meter $\left(\mathrm{mg} / \mathrm{m}^{3}\right)$ of total suspended particulate. The American Conference of Governmental Industrial Hygienists (ACGIH) also recomends a Threshold Limit Value (TLV) for nuisance dusts of $10 \mathrm{mg} / \mathrm{m}^{3}$ for total suspended particulate. (TLV's are also based on 8-hour time weighted average exposures.) In addition ACGIH recommends a TLV of $5 \mathrm{mg} / \mathrm{m}^{3}$ for respirable samples of nuisance dust.

These limits are for a normal work day and do not apply to brief exposures at higher concentrations, nor to substances which may cause irreversible physiologic impairment. Excessive concentrations of nuisance dusts may seriously reduce visibility, cause unpleasant deposits in the eyes, ears, and airway passages, and cause injury to skin and mucous membranes by chemical and physical irritation. Nuisance dusts may slow down the clearance of non-inert dust particles by increasing the load on the body's dust clearing mechanisms. Nuisance particulates may also act to carry toxic materials adsorbed on their surface further into the lung than would be otherwise possible.

\section{Mineral Dust}

If airborne particulates contain greater than $1 \%$ by weight crystalline silica, they are no longer considered nuisance particulates; they are mineral dusts. The MSHA standard and ACGIH-TLV for mineral dusts employ the formula:

PEL or TLV $=\frac{10 \mathrm{mg} / \mathrm{m}^{3}}{\% \text { respirable quartz }}+2$

Where the "\% respirable quartz" is the percent by weight of quartz on each respirable filter sample, and "PEL" is the permissible exposure level. Therefore, each respirable dust sample for mineral. dust has an exposure limit based on its content of quartz.

Some research studies $(15,16,17)$ have suggested that exposures to quartz below a $0.1 \mathrm{mg} / \mathrm{m}^{3}$ are safe levels of exposure. The current NIOSH Recommended Standard for crystalline silica is $0.05 \mathrm{mg} / \mathrm{m}^{3}$.

\section{Metals}

Some metals are essential nutrients, but may also serve as health hazards if they accumulate in the body in sufficient quantity to poison certain physiologic mechanisms. Other metals serve no biologic purpose, but are capable of producing diseage. (18) 
Trace concentrations of metals may be found in raw materials used in the manufacture of Portland Cement. Exposure to metals may also be introduced during cement production due to the abrasion between rock and metal surfaces in crushing and milling, cutting and welding operations, and shaking and transporting of materials. These metals may be in elemental form, but will almost always be in the oxidized state or bound up as metal silicates.

The following is a list of the MSHA standards, ACGIH-TLV's, and NIOSH recomended standards for 28 metsls which were sampled for during this survey. (19) The MSHA standards and ACGIH-TLV's are listed in $\mathrm{mg} / \mathrm{m}^{3}$ as 8 -hour time weighted average concentrations and based on samples of the "total" suspended particulate. A dash indicates that either no standard or TLV exists or no standard or TLV exists for the metal in the form it is likely to be encountered in a Portland cement plant. A "ceiling" designation means that exposure to the metal at the noted concentration should not be exceeded even instantaneausly. NIOSH reconmended standards are based on a 10 hour time weighted average exposure.

\begin{tabular}{|c|c|c|c|}
\hline Metal & MSHA-PEL & ACGIH-TLV & NIOSH \\
\hline Aluminum & - & 10 & - \\
\hline Arsenic & 0.5 & 0.2 & 0.002 \\
\hline Beryllium & 0.002 & 0.002 & - \\
\hline Calcium & - & - & - \\
\hline Cadmium & 0.2 & 0.05 & 0.04 \\
\hline $\begin{array}{l}\text { Chromium -VI } \\
\text { Cobalt }\end{array}$ & $\begin{array}{l}0.1 \text { ceiling } \\
0.1\end{array}$ & $\begin{array}{l}0.05= \\
1.0\end{array}$ & 0.001 \\
\hline Copper & 1.0 & 1.0 & - \\
\hline Iron & 10.0 & 5.0 & - \\
\hline Le ad & 0.2 & 0.15 & 0.1 \\
\hline Lithium & - & - & - \\
\hline Magnesium & 10.0 & 10.0 & - \\
\hline Manganese & 5.0 & 5.0 & - \\
\hline Molybdenium & 5.0 & 1.0 & 1.0 \\
\hline Nicke 1 & 1.0 & 1.0 & 0.15 \\
\hline Phosphorous & 0.1 & 0.1 & - \\
\hline Platinum & 0.002 & 0.002 & - \\
\hline Selenium & 0.02 & 0.02 & - \\
\hline Sodium & - & - & - \\
\hline Tellurium & 0.1 . & 0.1 & - \\
\hline Thallium & 0.1 & 0.1 & - \\
\hline $\operatorname{Tin}$ & 2.0 & 2.0 & - \\
\hline Titanium & 10.0 & 10.0 & - \\
\hline Vanadium & 0.5 ceiling & 0.05 & - \\
\hline Yttrium & 1.0 & 1.0 & 0.05 \\
\hline 2 ine & 5.0 & 5.0 & 5.0 \\
\hline Zirconium & 5.0 & 5.0 & - \\
\hline
\end{tabular}




\section{Alkali Dust}

Portland Cement and some raw materials used in the manufacture of Portland Cement are alkali dusts. They are materials more basic than the mucous lining of the respiratory airways. ( $\mathrm{pH}=7.4$ ) These dusts may cause irritation of the eyes and respiratory tract and erosion of the nasal septum. (20)

There are no general guidelines for limiting exposure to alkaline dusts based on their alkalinity or $\mathrm{pH}$. We may compare the $\mathrm{pH}$ of dusts collected in the cement plant to the $\mathrm{pH}$ of other alkali dusts. (20)

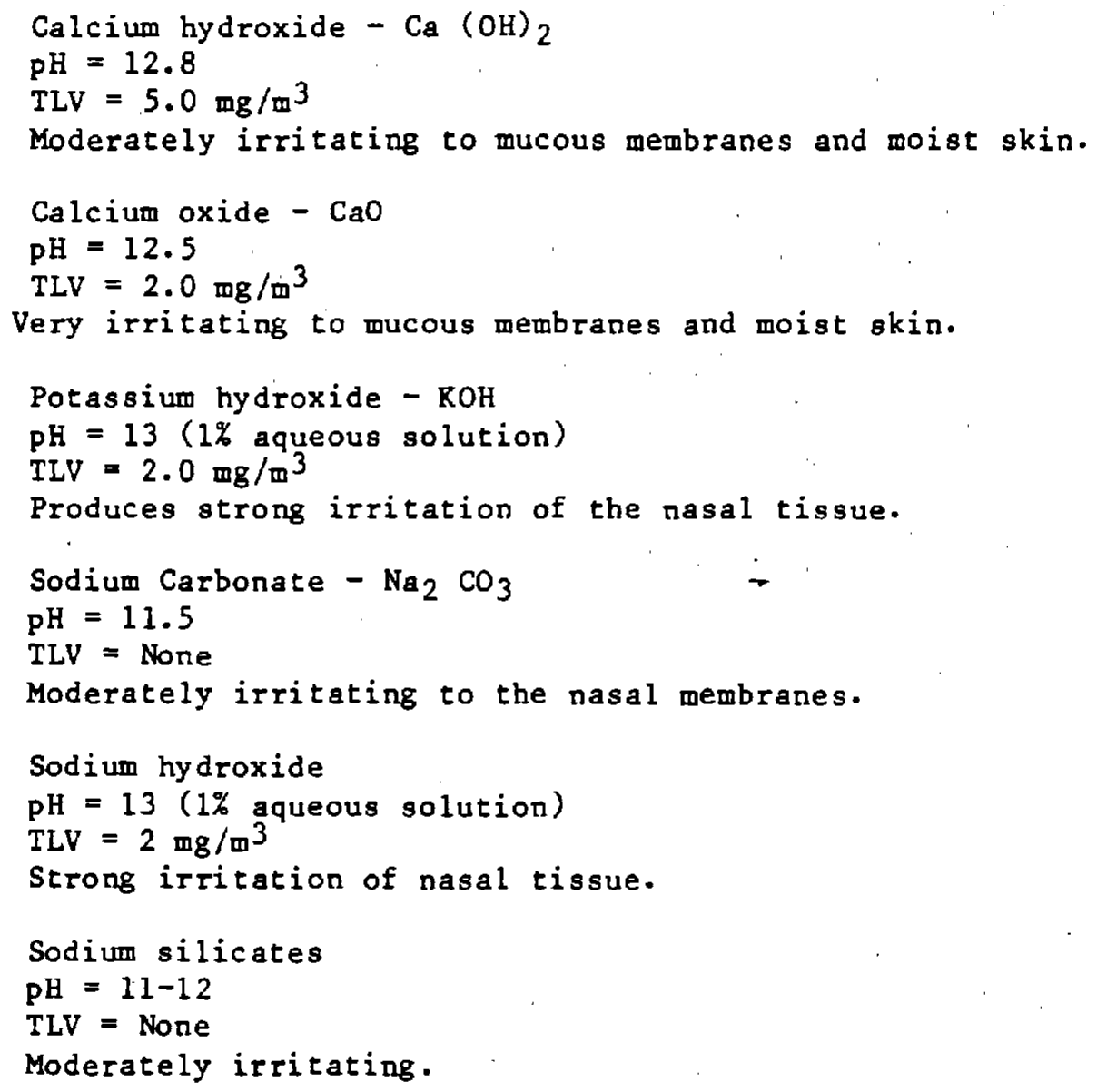

\section{Nitrogen Dioxide}

Nitrogen dioxide is a reddish-brown gas which is a comon contaminant in the exhaust of internal combustion engines. It is an irritant to the mucous membranes, and inhalation even at low concentrations may cause coughing, sometimes severe, which may be accompanied by mild or transient headache. (21)

Based on animal studies ACGIH recomends a short term exposure limit (STEL-the maximal concentration which workers can be exposed for a period up to 25 minutes) of $5 \mathrm{ppm}$. (14) This level was considered 
sufficiently low to insure against imediate injury or adverse physiologic effects from prolonged daily exposures. The present federal standard (MSHA and OSHA) for nitrogen dioxide is 5 pPm as an 8-hour time weighted average (TWA). (19) This was based upon the ACGIH TLV except that the STEL designation was omitted. (21) A number of human experiments and animal studies suggest that humans with normal respiratory function may be affected by exposure at or below this level and that the conditions of workers with diseases such as bronchitis may be aggravated by such exposures. $(22,23,24,25)$ NIOSH recomends a ceiling of 1 ppm to protect workers with preexisting chronic bronchitis. ACGIH maintains a STEL of $5 \mathrm{pPm}$ and a TWA of $3 \mathrm{ppm}$.

\section{Carbon Monoxide}

Carbon monoxide is a colorless, almost odorless gas, which is encountered as a product of incomplete combustion of almost any carbonaceous material. Carbon monoxide is a chemical asphyxiant, which rapidly diffuses across the alveolar membrane and reversibly binds with hemoglobin resulting in a reduction in the oxygen-carrying capacity of the blood. This reduction in oxygen-carrying capacity has adverse effects, and may lead to tissue injury.(14)

The signs and symptoms of acute exposure to high concentrations of Co are well known and easily recognized. These may include headache, nausea, vomiting, dizziness, drowsiness, and loss of consciousness. There are conflicting reports of effects to exposures at and below 100 PPm. (26,27) ACGIH recommends a TLV of $50 \mathrm{ppm}$ since prolonged exposure to this concentration should not result in blood co levels above 10 percent, a level above which the development of Clinical symptoms such as headache, fatigue, and dizziness occur. (28) The federal standard for carbon monoxide is also $50 \mathrm{ppm}$ for an 8 hour exposure time.

The effect of carbon monoxide is increased by factors such as an increase in physical activity, high environmental temperatures, high altitudes, and simultaneous exposure to narcotic solvents. Also, individual variability in cardiovascular disease status, ability to take up $\mathrm{CO}$, and smoking habits may augment the effects of $\mathrm{CO}$. NIOSH recommends $35 \mathrm{ppm}$ as a TWA and 200 as an excursion limit to provide a margin of safety for the employee with chronic heart disease. (29)

$\begin{array}{lccc}\text { Substance } & \text { MSHA-PEL-PPm } & \text { ACGIH-TLV-PPE } & \text { NIOSH-PPM } \\ \text { Nitrogen dioxide }\left(\mathrm{NO}_{2}\right) & 5 & 3 & \text { Ceiling - } 1 \\ \text { Carbon monoxide }(\mathrm{CO}) & \text { STEL }-5 & 35\end{array}$

V. RESULTS

Respirable Dust and Crystalline Silica

The personal respirable dust samples range from 0.32 to 4.18 $\mathrm{mg} / \mathrm{m}^{3}$. None of the respirable dust measurements exceed $5 \mathrm{mg} / \mathrm{m}^{3}$. Quartz was detected in two of the samples; one sample was collected from 
a painter in the mill room of Plant 3 , the other from a driller in the quarry. Neither of these samples exceed the MSHA standard or ACGIH-TLV for mineral dusts, nor are they above the $0.1 \mathrm{mg} / \mathrm{m}^{3}$ level recommended by other researchers. Both samples are above the NIOSH recomended 8 tandard of $0.05 \mathrm{mg} / \mathrm{m}^{3}$. The area respirable dust measurements indicate that low levels of quartz are present in the workroom air of the mills and packhouses. Cristobalite was not detected on any of the respirable dust filters.

Eight respirable dust samples were analyzed for content of 28 elements. The respirable dust sample is designed to collect only those particles capable of being deposited in the alveolar regions of the lung where gas exchange takes place. These measurements represent the concentration of elements in dust effecting this region of the lung.

\section{Total Dust and Trace Elements}

Six personal total dust measurements exceeded the MSHA standard and ACGIH-TLV of $10 \mathrm{mg} / \mathrm{m}^{3}$ for nuisance total dust. These measurements were collected from a primary crusher operator, a front end loader operator working on the coal pile at Plant 2, and four laborers working in various areas of the plant.

The "total" aerosol should always be sampled when the air contaminant is a material capable of affecting body systems other than the lung. (18) The total dust sample not only collects respirable particles, but larger particles which are captured in the nose, throat, and upper airways. Contaminants may affect these areas, or they may be swallowed, exerting their affects through the digestive system. Particles in the larger size ranges may also irritate the eyes leading to conjunctivitis. Occupational health standards and guidelines for trace elements are based on total dust sampling.

Only one of these samples contained elements in concentrations greater than the standards or recomended guidelines. A welder, constructing handrails in the mill in plant 3 was exposed to excessive particulate and iron and phosphorus fume. He was using iron-based welding rods.

The lower limit of detection for these elements is 0.001 milligrams per filter. The following elements were below the limit of detection for all filters:

$\begin{array}{lll}\text { arsenic } & \text { lithium } & \text { tellurium } \\ \text { beryllium } & \text { platinum } & \text { thallium } \\ \text { cadmium } & \text { selenium } & \text { yttrium } \\ \text { cobalt silver } & \text { zirconium } & \end{array}$

\section{Aerodynamic Particle Sizing}

About $30 \%$ of the airborne particle mass in the packhouse is below 10 in diameter. About $15 \%$ of the dust mass in the mill area is 
below $10 \mathrm{Hm}$. More than half of the airborne particle mass is greater than $20 \mathrm{Hm}$ in both areas. Particles greater than 20-30 Hom in

diameter have less probability of being inhaled than smaller particles.

Bulk Material

Quartz was found in bulk material samples of crushed limestone at concentrations of 8.3 and $8.6 \%$. Quartz was also detected in dust collected from a rafter in the millroom of Plant 3 , where raw materials are milled, and in waste kiln dust at the back end of kilns in Plant 2 and 3. The only finished cement product found to contain quartz was masonry cement. No cristobalite was found in any of the bulk samples.

Quartz is comonly found in limestone and other raw materials used for the production of cement. Therefore, particulates around the quarry, crushers, raw mills, blending bins, and at the feed end of kilns may contain quartz. There may be variation in quartz concentration depending on the composition of the overburden and ore that employees are working with. Also, the mixing and grinding of the limestone with other materials will result in a range of concentrations. Therefore, the free silica concentrations may vary with area and time.

After materials pass through the high temperatures of the kiln, they become altered morphologically and chemically, so that the quartz content is greatly reduced or nonexistent. This is evident by the fact that no quartz is detected in the clinker samples. Crystalline silica is generally not found in finished cement, but some sand materials containing quartz are added to masonry and mortar type cements. No cristobalite was found in any of the bulk samples.

Roughly, $2 \%$ of all bulk samples were aluminum. No chromium, cobalt, or nickel was detected in any of the bulk samples. Magnesium was present in concentrations ranging from 0.46 to $0.71 \%$, and manganese from 0.08 to $0.15 \%$. Because chromium in the +6 valence state is considered more toxic than trivalent chromium or chromium in the +3 valence state, the bulk samples were analyzed for hexavalent chromium. The analytical test for hexavalent chromium is more sensitive than total chromium; therefore, hexavalent chromium was detected in some bulk samples even though no total chromium was. The range of hexavalent chromium was from non-detectable to $0.005 \%$. In order to be exposed to $0.001 \mathrm{mg} / \mathrm{m}^{3}$ of hexavalent chromium which is the NIOSH recommended standard, a worker would have to be exposed to about $20.0 \mathrm{mg} / \mathrm{m}^{3}$ of airborne dust.

\section{$\mathrm{pH}$ Analysis}

The $\mathrm{pH}$ of the particulates range from 10.0 to 11.9 , indicating that all dusts are alkaline. Raw material dust had the lowest alkalinity and clinker the highest. The $\mathrm{pH}$ of these dusts fall within the range of other alkaline dusts known to be mildly irritating to the nose and other airways. The $\mathrm{pH}$ of all dusts were below those alkaline materials which are strong irritants or that severely damage nasal tissue. 


\section{Nitrogen Dioxide}

The highest nitrogen dioxide concentration recorded was $0.18 \mathrm{ppm}$. None of the nineteen samples for nitrogen dioxide exceeded the federal $s$ tandard or ACGIH-TLV. Although these are long-term samples and do not give peak or instantaneous concentrations, the levels are so low, it is doubtful that any of the workers were exposed even momentarily to concentrations greater than $1.0 \mathrm{ppm}$.

\section{Carbon Monoxide}

Readings for carbon monoxide were taken in the maintenance shop at the quarry, while a mechanic was working on a gasoline powered forklift. After the engine had run 45 seconds we detected a peak of 40 ppm, holding steady at 30-35 ppm for 6 minutes. After 6 minutes the level of carbon monoxide gradually decreased to below 5 ppm. Readings were also taken in the packhouse while loaded pallets were being moved out by a gasoline powered forklift. Momentary readings as high as 100 PPm were detected in the packhouse. While gasoline or diesel powered machines are being operated, particularly indoors, levels of carbon monoxide may build up to concentrations capable of causing effects on employees.

\section{Water Analysis}

No elements, pesticides, or herbicides were found to exceed the analytical lower limit of detection except flouride, and concentrations of this chemical were below mandatory guidelines:

\section{DISCUSSION AND CONCLUSION}

Employees at the Ideal Cement Plant who work in raw material or masonry cement contaminated areas, are exposed to low levels of quartz. Quartz is a common contaminant of dust found in Portland Cement Plants, but at generally low levels. Although silicosis is not a common disease of Portland Cement workers, exposure to levels of quartz does present some risks. Efforts should continue to be made to keep exposure to crystalline silica dusts as low as possible.

Samples from six workers exceeded the MSHA standard and ACGIH-TLV for total nuisance dust. Workers exposed to excessive total dust may experience irritation of the eyes, nose, throat, and upper airways. The dusts throughout the plant may be irritating to the nose, throat, and upper airwayg, but the alkalinity is such that there should be no serious damage to body tissue.

The concentration of metals found in dusts to which workers are exposed are below hazardous concentrations. Of workers at Ideal cement, it appears that only welders may be exposed to metals in excessive quantities and these metals originate from the welding rods, and not from airborne dusts. 
We found no substances either in the plant atmosphere or community drinking water in concentrations toxic to the kidneys. Although a previous NIOSH health hazard evaluation noted a low mean creatinine clearance in uranium millers and Portland Cement workers, other tests were all within published normal limits. An explanation for the low creatinine clearance was offered in the NIOSH report: "It is possible that the low creatinine clearances for both groups, particularly for the cement production workers, may have been due to the effect of physical exertion upon renal blood flow, and thus upon clearance of endogenous creatinine. Population "normals" as reported in the literature, are derived from 24 hour collections of urine, frequently in hospital settings. Since we know that factors such as renal blood flow and the production of creatinine by skeletal muscle use affected by posture and physical exertion, resting creatinine clearances may differ from those during physical exertion." In addition to physical activity, important factors which possibly resulted in low values of creatinine clearance were the short collection period and inherent difficulties in assuring that urine collection was complete. Field measurements of creatinine clearance are imprecise, particularly when collected only over an 8-hour period.

Carbon monoxide from the exhaust of diesel and gasoline powered equipment may build up in enclosed areas such as the packhouse and maintenance garages. Concentrations may reach levels capable of causing effects on workers in these areas.

\section{RECOMENDATIONS}

Engineering controls are the most effective means of reducing worker exposure to airborne dust. These controls should be maintained in efficient working order. Ventilation design to remove the dust from the air once it is generated and separation from the dust by enclosing either the worker or the dust are effective means of control. The priority for implementing dust control measures should begin with areas. of highest exposue. Workers with the highest dust exposures are generally involved in maintenance and clean-up operations. Since it is difficult to control dust exposures during these operations, personal respirators may need to be provided. Packers, however, are generally stationary. Local exhaust ventilation is provided on the bagging machines. However, there are frequent occurrences i.e., bags rupturing, misconnection of bags on feeder, and dropping of bags onto conveyor which generate large amounts of dust. Ventilation fans may be placed above or behind packers to blow this fugitive dust away from their breathing zone. Helmets attached to ventilation hoses, which supply air to cool the workers and prevent dust from entering the helmet, are an effective control measure for stationary workers who cannot be enclosed from dust sources.

The primary crusher operator station might be enclosed to protect him from noise and excessive dust. Also, the cab of the front end loader might be maintained to provide a tighter seal to outside air. These enclosures would reduce the amount of fugitive emissions to which the workers would be exposed. 
Although engineering controls are the recomended course of action, personal protective equipment (respirators and goggles) may be used by workers whenever engineering controls are not available or during maintenance, repair, and cleanup operations. Respirators, such as the disposable paper or cloth respirators do not form an occlusive seal between the respirator and the face. Dust particles would be able to pass through leaks between the respirator and the face. Whenever workers are potentially exposed to excessive quartz concentrations, quarter or half mask dust-fume-mist respirators should be used. The disposable respirators will, however, provide some protection to workers exposed to nuisance particulates. If workers complain of eye irritation, full-face piece respirators may be used instead of half or quarter mask respirators to alleviate the problems. It is suggested that workers be involved in the selection of a comfortable NIOSH/MSHA approved dust-fume-mist respirator and be fit-tested to insure that they are adequately protected. (23)

To reduce the emission of carbon monoxide from engine exhaust in enclosed areas, engines should be shut off or parked outside when not in use. During the loading of bulk material trucks, engines should be shut off to avoid a build-up of gases in the silo control rooms. Increased general room ventilation in the packing building would also reduce exhaust gas conentrations. For operations in low volume buildings, such as the packhouse, gasoline powered forklifts might be replaced by electric or propane powered forklifts. Propane exhaust generally contains less carbon monoxide.

A routine monitoring program is recommended for areas of the cement plant. Workers associated with raw materials and masonry cement may need to be monitored further to make sure respirable quartz concentrations remain below recommended exposure levels. Carbon monoxide levels in the packhouse and maintenance garages may need to be checked during heavy activity.

The corrective actions recommended should be viewed as scientific guidance. There is no legal requirement that any of these recommendations be implemented, and there is no guarantee that if implemented, they would be sufficient to prevent future citations for non-compliance. Nevertheless, it is anticipated that implementation of the recommendations listed in this report will reduce airborne dust levels at this facility, and improve the environmental conditions of the workplace.

\section{REFERENCES}

1. Shreve, R., Brink, J; Chemical Process Industries, McGraw-Hi11, New York, New York, 1977; 156-162.

2. Skalny, J., Daugherty, R., Everything you always wanted to know about Portland Cement;. Chemtech, Jan 1972, Vol 41. 
3. Caplan, K., Doemeny, L., Sorenson, S., "Performance Characteristics of the $10 \mathrm{~mm}$ Cyclone Respirable Mass Sampler," American Industrisl Hygiene Assoc. Journal Vol 38, Feb 77, P 87.

4. Hatch, T., "Developments in the sampling of Airborne Dust," Archives Industrial Hygiene and Occupational Med., 11:212-217 (1955).

5. Ogden, T., "Inhalable, Inspirable, and Total Dust", International Symposium Proceedings on Aerosols in the Work Environment, Minneapolis, Nov 1981.

6. NIOSH Manual of Analytical Methods, "Free Silica (Quartz, Cristobalite, Trilaymite) in Airborne Dust", 2nd Edition, USDHEW Publications, 1977, P \& CAM 259.

7. NIOSH Manual of Analytical Methods, "Trace Elements", USDHHS, Vo1 7, P \& CAM 351 . At lanta, GA,

8. Operating Manual for Andersen 2000, Andersen 2000 Inc., 1976.

9. Palmes, E., "Personal Sampler for Nitrogen Dioxide", American Ind. Hyg. Assoc. J., Oct 1976, Vol 37, 570-577.

10. Hearl, F., "Industrial Hygiene Studies of Diesel Emissions in Coal Mines, NIOSH, 1981.

11. Interscan Corporation, Instruction Manual for Interscan Model LD-14- Carbon Monoxide Monitor, Chatsworth, CA.

12. NIOSH Manual of Analytical Methods, "Trace Elements", Vol 7 , P \& CAM 351, 1981.

13. NIOSH Manual of Analytical Methods, "Hexavalent Chromium", Vol 6, P \& CAM 319, 1980.

14. American Conference of Governmental Industrial Hygienists, Documentation of the Threshold Limit Values, 4th Edition, Cincinnati, OH, 1980.

15. Ayer, H., "The Proposed ACGIH Mars Limits for Quartz - Review and Evaluation", American Industrial Hygiene Assoc. J., 30, 117, 1969.

16. Hosey, A., et al, "Control of Silicosis in Vermont Granite Industry", PHS Publication 557, Washington, D.C. (1957).

17. Sutton, G., "Respirable Mass Concentrations Equivalent to Impinger Count Data", Presented at 1968 annual meeting Am. Ind. Hyg. Assoc., St. Louis, Mo. 
18. Cassarett \& Doul1, Toxicology: The Basic Science of Poisins, MacMillan Col,, New York, 1975.

19. U.S. Department of HEW, "Pocket Guide to Chemical Hazards", Sept 1978.

.. 20. Patty, F., Industrial Hygiene and Toxicology, Interscience Co. New York, Vol 2, 1963, p 859-869.

21. NIOSH Occupational Exposure to Oxides of Nitrogen, Criteria for a recommended standard. National Institute for Occupational Safety and Health, 1976.

22. Von Nieding, G., et a1, Protective action of atropine mescaline and orciprenaline on provations lists with $\mathrm{NO}_{2}$ in healthy subjects and patients with chronic non-specific bronchitis, In Arch Arbeitsmed, 29:55-63, 1971 .

23. Von Nieding, et a1, "Studies of the acute effects of $\mathrm{NO}_{2}$ on lung function, influence on diffusion, perfusion and ventilation in the lungs", Int Arch. Arbeitsmed, 31:61-72, 1973.

24. Kosmider, S., et al, Zentralbl. Arbeitsmed, 22:362, 1972.

25. Vigordortschik, N. et al, J. Ind. Hygiene and Toxicology, $19: 469,1937$.

26. Carbon Monoxide - a bibliography with abstracts. Compiled by A.G. Cooper, U.S. PhS, Pub. No. 1503, 1966.

27. Haperin, M., et al, "The time-course of effects of carbon monoxide on visual thresholds", J. of Physiol, Vol 146:583-593, 1959.

28. Ebersole, J New England J. of Med, Vol 262:599, 1960

29. NIOSH, Occupational Exposure to Carbon Monoxide, Criteria for a recommended standard. National Institute for Occupational Safety and Health, 1972.

30. NIOSH, A Guide to Industrial Respiratory Protection, Dept of H.E.W., June 1976.

IX. AUTHORSHIP AND ACKNOWLEDGEMENTS

Report Prepared By:

\author{
Wayne T. Sanderson \\ Industrial Hygienist \\ Division of Respiratory \\ Disease \\ 944 Chestnut Ridge Road \\ Morgantown, West Virginia
}


Survey Assistance:

Originating office:

Report Typed By:
Bobby J. Gunter, Ph.D.

Regional Industrial Hygienist NIOSH Region VIII

Denver, Colorado

Greg J. Kullman

Industrial Hygienist

Division of Respiratory

Disease

944 Chestnut Ridge Road

Morgantown, West Virginia

Mining Hazard Evaluation and Technical Assistance Program Division of Respiratory Disease Studies 944 Chestnut Ridge Road Morgantown, West Virginia

Ann Stanley

\section{DISTRIBUTION AND AVAILABILITY}

Copies of this report are currently available upon request from NIOSH, Division of Standards Development and Technology Transfer, Information Resources and Dissemination Section, 4676 Columbia Parkway, Cincinnati, Ohio 45226. After 90 days the report will be available through the National Technical Information Service (NTIS), Springfield, Virginia. Information regarding its availability through NTIS can be obtained from NIOSH, Publications office, at the Cincinnati address.

For the purpose of informing affected employees, a copy of this report $s$ hall be posted in a prominent place accessible to the employees for a period of 30 calendar days.

Copies of this report have been sent to:

Mr. Leonard R. Sheridan

United Steelworkers of America

941 E. 17 th Avenue

Denver, Colorado 80218

Mr. Jacob Shafer

Idea 1 Cement Company

P.O. Box 231

Florence, Colorado 81226 
Mr. Al Klashak

Ideal Basic Industry

Cement Division

P.0. Box 8789

Denver, Colorado 80201

- Bobby J. Gunter, Ph.D.

Regional Industrial Hygienist

NIOSH Region VIII

Denver, Colorado 80294 
TABLE 1

PERSONAL RESPIRABLE DUST AND QUARTZ CONCENTRATIONS REPORTED IN MILLIGRAMS PER CUBIC METER - $\mathrm{mg} / \mathrm{m}^{3}$

Ideal Cement - Florence, Colorado

Sample 非 Job Area Concentration Concentration Quartz TLV

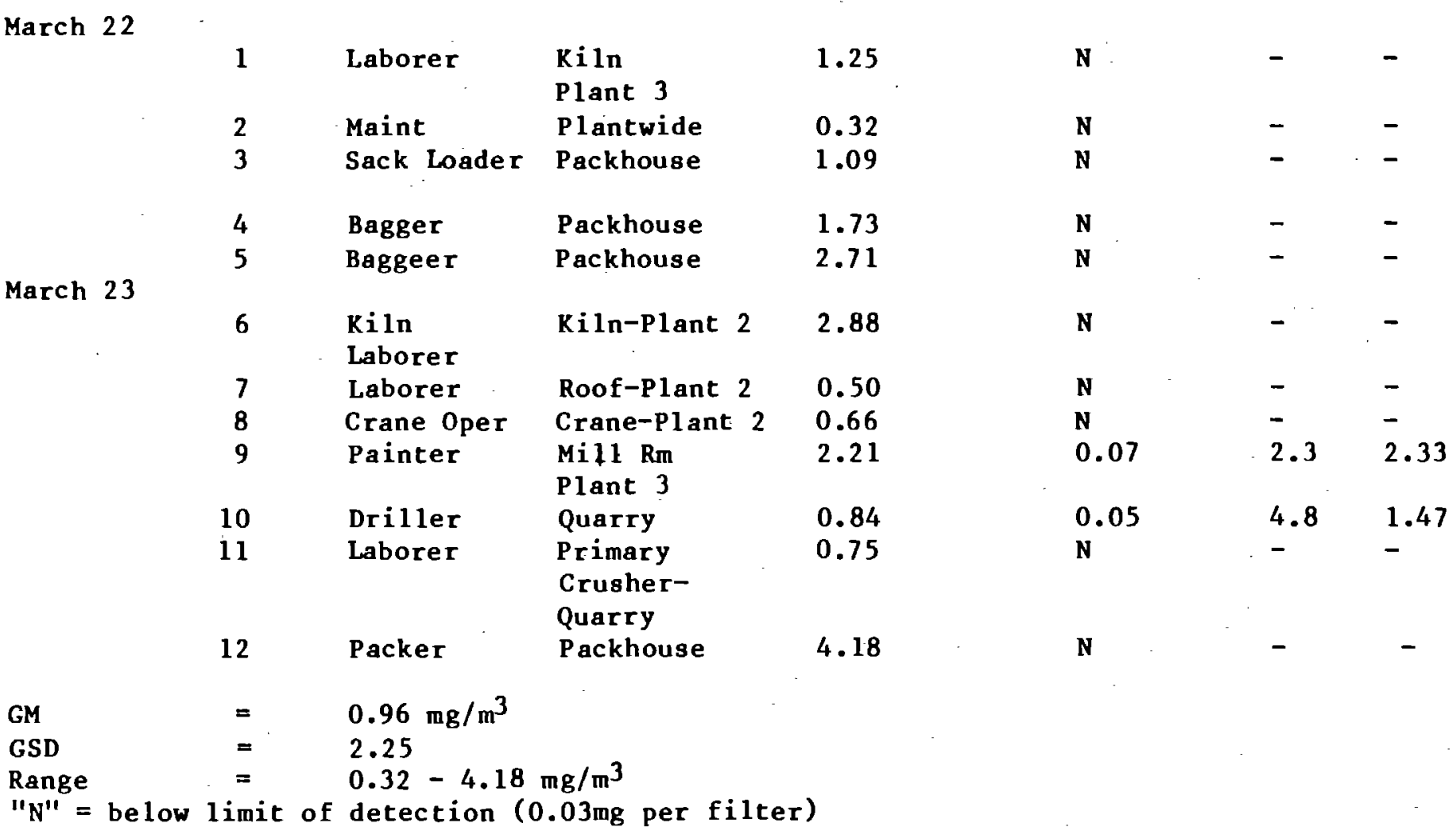


TABLE 2

TRACE ELEMENTS CONCENTRATIONS FROM PERSONAL RESPIRABLE DUST SAMPLES REPORTED IN MILLIGRAMS PER CUBIC METER (mg/m 3 )

Ideal Cement - Florence, Colorado

March 22, 1982

\begin{tabular}{|c|c|c|c|c|c|}
\hline Elements & $\begin{array}{c}\text { Laborer } \\
\text { Mill Plant } \$ 3\end{array}$ & $\begin{array}{c}\text { lst } \\
\text { Laborer } \\
\text { Mill Plant } \sharp 3 \\
\end{array}$ & $\begin{array}{l}\text { ift } \\
\text { Repairman } \\
\text { Plantwide }\end{array}$ & $\begin{array}{l}\text { Driller } \\
\text { Quarry }\end{array}$ & $\begin{array}{c}\text { Crusher Oper } \\
\text { Quarry }\end{array}$ \\
\hline A1 & 0.095 & 0.016 & 0.009 & $\mathrm{~N}$ & 0.009 \\
\hline $\mathrm{Ca}$ & 1.637 & 0.370 & 0.180 & 0.182 & 0.449 \\
\hline Co & $\mathrm{N}$ & $\mathrm{N}$ & $\mathrm{N}$ & $\mathbf{N}$ & $\mathrm{N}$ \\
\hline $\mathrm{Cu}$ & $\mathrm{N}$ & $\mathrm{N}$ & $\mathrm{N}$ & $\mathrm{N}$ & $\mathrm{N}$ \\
\hline $\mathrm{Fe}$ & 0.102 & 0.025 & 0.103 & 0.027 & 0.017 \\
\hline $\mathrm{Mg}$ & 0.031 & 0.005 & 0.002 & $\mathrm{~N}$ & 0.004 \\
\hline $\mathrm{Mn}$ & 0.006 & 0.001 & 0.002 & $\mathbf{N}$ & 0.001 \\
\hline Mo & $\mathrm{N}$ & $\mathrm{N}$ & $\mathrm{N}$ & $\mathrm{N}$ & $\mathrm{N}$ \\
\hline $\mathrm{Na}$ & 0.004 & 0.003 & 0.003 & 0.002 & $\mathrm{~N}$ \\
\hline $\mathrm{Ni}$ & $\mathbf{N}$ & $\mathrm{N}$ & $\mathbf{N}$ & $-\mathbf{N}$ & N \\
\hline $\mathbf{P}$ & 0.005 & 0.002 & 0.002 & $\mathrm{~N}$ & $\mathrm{~N}$ \\
\hline $\mathrm{Pb}$ & $\mathrm{N}$ & $\mathbf{N}$ & $\mathrm{N}$ & $\mathbf{N}$ & $\mathrm{N}$ \\
\hline Sn & $\mathbf{N}$ & N & N & N & $\mathrm{N}$ \\
\hline Ti & 0.003 & $\mathbf{N}$ & $\mathbf{N}$ & $\mathrm{N}$ & $\mathrm{N}$ \\
\hline $\mathrm{V}$ & $\mathbf{N}$ & $\mathbb{N}$ & $\mathrm{N}$ & N & $\mathrm{N}$ \\
\hline $2 n$ & $\mathbf{N}$ & $\mathrm{N}$ & 0.005 & $\mathrm{~N}$ & $\mathrm{~N}$ \\
\hline
\end{tabular}


TABLE 2

TRACE METAL CONCENTRATIONS FROM RESPIRABLE DUST SAMPLES REPORTED IN MILLIGRAMS PER CUBIC METER (mg/m ${ }^{3}$ )

Ideal Cement - Florence, Colorado

March 23, 1982

lat Shift

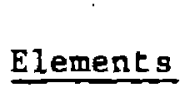

AI

$\mathrm{Ca}$

$\mathrm{Cr}$

$\mathrm{Cu}$

$\mathrm{Fe}$

$\mathrm{Mg}$

$\mathrm{Mn}$

Mo

$\mathrm{Na}$

$\mathrm{Ni}$

$P$

$\mathrm{Pb}$

Sn

$\mathrm{Ti}$

$v$

$2 \mathrm{n}$
Repairman

Plant 2

0.024

0.423

N

$N$

0.075

0.005

0.002

$\mathrm{N}$

0.001

$\mathrm{N}$

0.002

$\mathrm{N}$

N

$\mathrm{N}$

N

N
Truckdriver

Quarry

$$
0.004
$$

0.065

$\mathrm{N}$

$\mathrm{N}$

0.004

$\mathrm{N}$

$N$

N

0.001

$\mathrm{N}$

N

N

N

N

N

0.003
Bobcat Oper

Plant 2

0.021

0.389

0.003

$\mathrm{N}$

0.023

0.005

$\mathrm{N}$

N

0.008

$\mathrm{N}$

0.002

0.002

$\mathrm{N}$

N

$\mathrm{N}$

0.006 
TABLE 3

PERSONAL TOTAL DUST CONCENTRATIONS

REPORTED IN MILLIGRAMS PER CUBIC METER - $\mathrm{mg} / \mathrm{m}^{3}$

Ideal Cement - Florence, Colorado

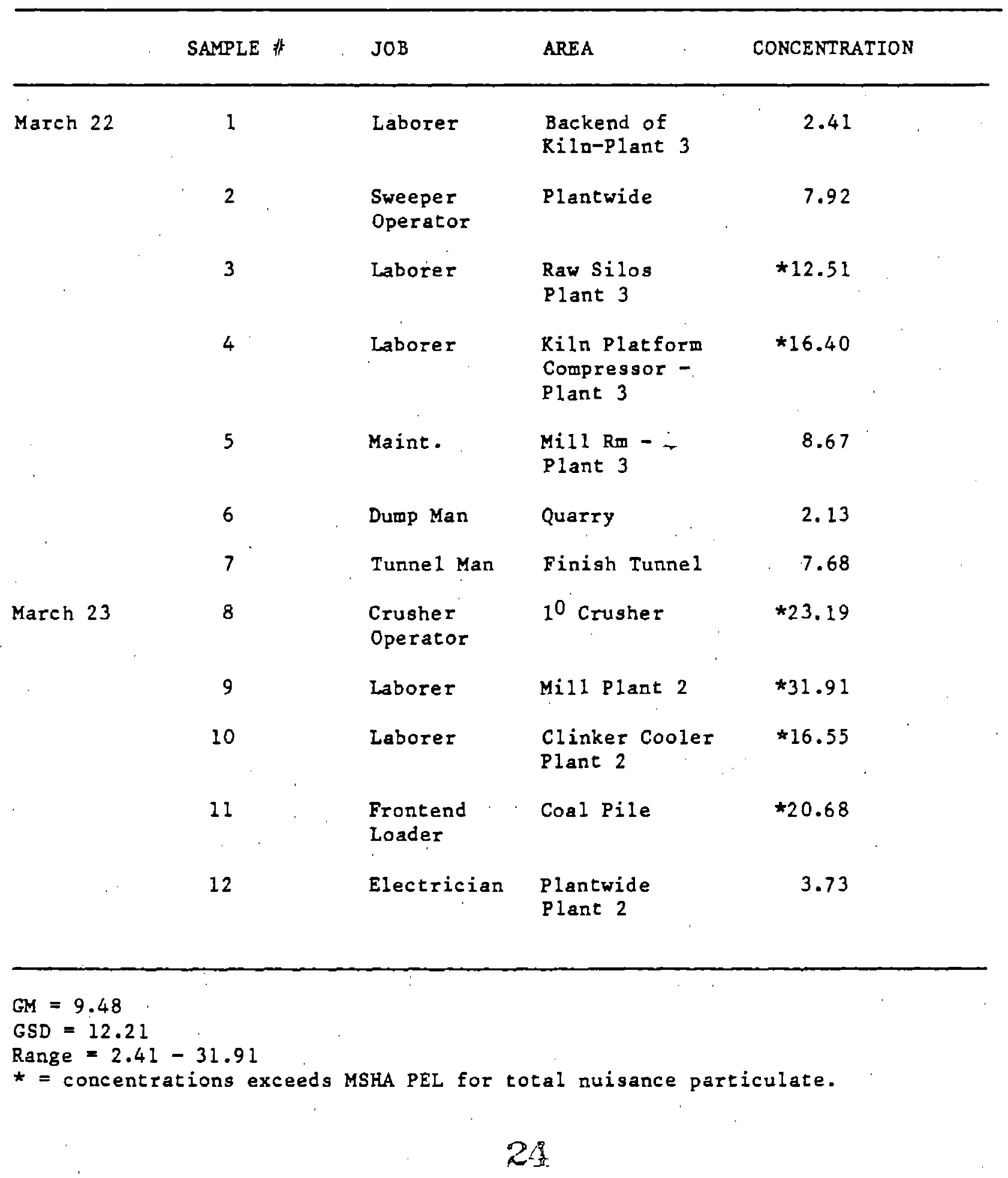


TABLE 4

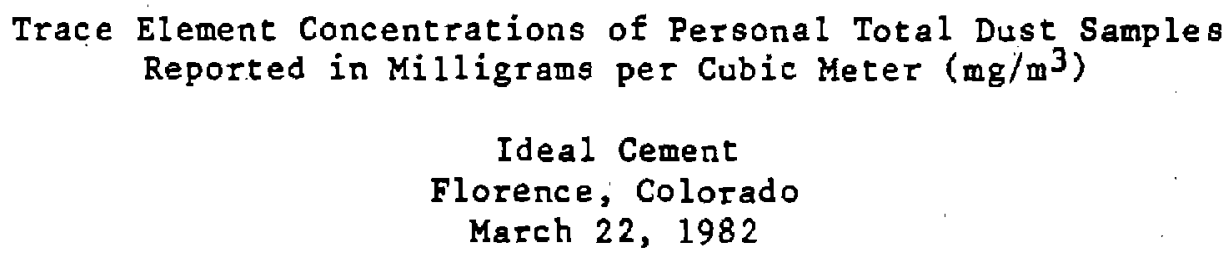

lst Shift

\begin{tabular}{cllcc} 
Elements & $\begin{array}{l}\text { Laborer } \\
\text { Plant 3 }\end{array}$ & $\begin{array}{c}\text { Sweeper } \\
\text { Plantwide }\end{array}$ & $\begin{array}{c}\text { Laborer } \\
\text { Top-RawSilos }\end{array}$ & $\begin{array}{c}\text { Laborer } \\
\text { Kiln-Plant 3 }\end{array}$ \\
\hline A1 & 0.005 & 0.070 & 0.069 & 0.148 \\
$\mathrm{Ca}$ & 0.120 & 1.435 & 1.629 & 2.825 \\
$\mathrm{Cr}$ & $\mathrm{N}$ & $\mathrm{N}$ & $\mathrm{N}$ & $\mathrm{N}$ \\
$\mathrm{Cu}$ & $\mathrm{N}$ & $\mathrm{N}$ & $\mathrm{N}$ & $\mathrm{N}$ \\
$\mathrm{Fe}$ & 0.005 & 0.109 & 0.104 & 0.119 \\
$\mathrm{Mg}$ & 0.003 & 0.027 & 0.049 & 0.047 \\
$\mathrm{Mn}$ & $\mathrm{N}$ & 0.005 & 0.007 & 0.009 \\
$\mathrm{Mo}$ & $\mathrm{N}$ & $\mathrm{N}$ & $\mathrm{N}$ & $\mathrm{N}$ \\
$\mathrm{Na}$ & 0.003 & 0.011 & 0.011 & 0.017 \\
$\mathrm{Ni}$ & $\mathrm{N}$ & $\mathrm{N}$ & $\mathrm{N}$ & $\mathrm{N}$ \\
$\mathrm{P}$ & $\mathrm{N}$ & 0.005 & 0.004 & 0.013 \\
$\mathrm{~Pb}$ & $\mathrm{~N}$ & 0.002 & $\mathrm{~N}$ & $\mathrm{~N}$ \\
$\mathrm{Sn}$ & $\mathrm{N}$ & $\mathrm{N}$ & $\mathrm{N}$ & $\mathrm{N}$ \\
$\mathrm{Ti}$ & $\mathrm{N}$ & 0.003 & 0.002 & .005 \\
$\mathrm{~V}$ & $\mathrm{~N}$ & $\mathrm{~N}$ & $\mathrm{~N}$ & $\mathrm{~N}$ \\
$\mathrm{Zn}$ & $\mathrm{N}$ & 0.001 & 0.004 & .002
\end{tabular}


Table 4 (Continued)

\begin{tabular}{|c|c|c|c|c|c|}
\hline & Maint & Welder & Dump Man & Tunnel Man & Bulkhead \\
\hline Elements & Mill & Plant 非 3 & Quarry & Packhouse & Finish Silos \\
\hline
\end{tabular}

$\begin{array}{llllll}\mathrm{Al} & 0.090 & 1.715 & 0.016 & 0.070 & 0.030 \\ \mathrm{Ca} & \mathrm{I} .595 & 21.355 & 0.295 & 1.264 & 0.523 \\ \mathrm{Co} & \mathrm{N} & \mathrm{N} & \mathrm{N} & \mathrm{N} & \mathrm{N} \\ \mathrm{Cu} & 0.002 & 0.006 & \mathrm{~N} & \mathrm{~N} & \mathrm{~N} \\ \mathrm{Fe} & 0.146 & 5.545 & 0.020 & 0.075 & 0.025 \\ \mathrm{Mg} & 0.008 & 0.759 & 0.008 & 0.021 & 0.008 \\ \mathrm{Mn} & \mathrm{N} & 0.447 & \mathrm{~N} & 0.004 & 0.002 \\ \mathrm{Mo} & \mathrm{N} & 0.004 & \mathrm{~N} & \mathrm{~N} & \mathrm{~N} \\ \mathrm{Na} & 0.004 & 0.461 & 0.005 & 0.019 & 0.001 \\ \mathrm{Ni} & \mathrm{N} & 0.007 & \mathrm{~N} & \mathrm{~N} & \mathrm{~N} \\ \mathrm{P} & \mathrm{N} & 0.101 & \mathrm{~N} & 0.003 & 0.002 \\ \mathrm{~Pb} & \mathrm{~N} & 0.007 & \mathrm{~N} & \mathrm{~N} & \mathrm{~N} \\ \mathrm{~S} & \mathrm{~N} & \mathrm{~N} & \mathrm{~N} & \mathrm{~N} & 0.002 \\ \mathrm{Ti} & \mathrm{N} & 0.063 & \mathrm{~N} & 0.003 & \mathrm{~N} \\ \mathrm{~V} & \mathrm{~N} & 0.007 & \mathrm{~N} & \mathrm{~N} & \mathrm{~N} \\ \mathrm{Zn} & \mathrm{N} & \mathrm{N} & \mathrm{N} & 0.001 & \mathrm{~N}\end{array}$




\begin{tabular}{|c|c|c|c|}
\hline \multicolumn{4}{|c|}{$\begin{array}{c}\text { Ideal Cement } \\
\text { Florence, Colorado } \\
\text { March } 23,1982\end{array}$} \\
\hline \multicolumn{4}{|c|}{ lst Shift } \\
\hline $\begin{array}{c}\text { Laborer } \\
\text { Mills Plant } \# 2\end{array}$ & $\begin{array}{c}\text { Laborer } \\
\text { Plant \#2 } \\
\text { Clinker Cooler } \\
\end{array}$ & $\begin{array}{l}\text { Front Ent Loader } \\
\text { Coal Pile Plant } 2 \\
\end{array}$ & $\begin{array}{l}\text { Electrician } \\
\text { Plant } 2 \\
\end{array}$ \\
\hline 0.114 & 0.142 & 0.006 & 0.726 \\
\hline $\begin{array}{l}2.459 \\
\mathrm{~N}\end{array}$ & $\begin{array}{l}2.571 \\
\mathrm{~N}\end{array}$ & $\begin{array}{l}1.283 \\
\mathrm{~N}\end{array}$ & $\begin{array}{l}0.726 \\
\mathrm{~N}\end{array}$ \\
\hline $\mathrm{N}$ & $\mathrm{N}$ & $\mathrm{N}$ & $\mathrm{N}$ \\
\hline 0.126 & 0.136 & 0.067 & 0.049 \\
\hline 0.042 & 0.038 & 0.016 & 0.012 \\
\hline 0.009 & 0.008 & 0.004 & 0.003 \\
\hline $\mathrm{N}$ & $\mathrm{N}$ & $\mathrm{N}$. & $\mathbf{N}$ \\
\hline 0.027 & 0.015 & 0.019 & 0.009 \\
\hline $\mathrm{N}$ & $\mathrm{N}$ & $\mathrm{N}$ & $\mathrm{N}$ \\
\hline 0.006 & 0.006 & 0.005 & 0.002 \\
\hline 0.004 & $\mathrm{~N}$ & $\mathrm{~N}$ & $\mathbf{N}$ \\
\hline $\mathbf{N}$ & $\mathbf{N}$ & $\mathbf{N}$ & $\mathbf{N}$ \\
\hline 0.007 & 0.005 & 0.002 & 0.002 \\
\hline $\mathbf{N}$ & $\mathrm{N}$ & $\mathrm{N}$ & $\mathrm{N}$ \\
\hline 0.011 & $\mathrm{~N}$ & 0.001 & 0.003 \\
\hline
\end{tabular}


Table 4 (Continued)

\begin{tabular}{|c|c|c|c|c|}
\hline Elements & $\begin{array}{r}\text { Repairman } \\
\text { Plant } \# 2 \\
\end{array}$ & $\begin{array}{l}\text { Miller } \\
\text { Plant } \# 2 \\
\end{array}$ & $\begin{array}{l}\text { Crusher Oper } \\
\text { Quarry } \\
\end{array}$ & $\begin{array}{c}\text { Shovel Oper } \\
\text { Quarry }\end{array}$ \\
\hline A1 & 0.052 & 0.320 & 0.065 & 0.006 \\
\hline $\mathrm{Cs}$ & 0.993 & 6.061 & 1.532 & 0.100 \\
\hline $\mathrm{Cr}_{r}$ & $\mathbb{N}$ & 0.006 & $\mathrm{~N}$ & $\mathrm{~N}$ \\
\hline $\mathrm{Cu}$ & $\mathbf{N}$ & $N$ & $\mathrm{~N}$ & 0.003 \\
\hline$\overline{E e}$ & 0.070 & 0.335 & 0.078 & 0.009 \\
\hline $\mathrm{Mg}$ & 0.015 & 0.092 & 0.032 & 0.004 \\
\hline $\mathrm{Mn}$ & 0.004 & 0.019 & 0.006 & $\mathbf{N}$ \\
\hline Mo & $\mathrm{N}$ & $N$ & $\mathrm{~N}$ & $N$ \\
\hline $\mathrm{Na}$ & 0.002 & 0.019 & 0.009 & 0.012 \\
\hline $\mathrm{Ni}$ & $\mathbf{N}$ & $\mathbf{N}$ & $\mathbf{N}$ & $\mathrm{N}$ \\
\hline $\mathbf{P}$ & 0.003 & 0.015 & 0.006 & $\mathbf{N}$ \\
\hline $\mathrm{Pb}$ & $\mathrm{N}$ & $\mathrm{N}$ & $\mathrm{N}$ & $\mathbf{N}$ \\
\hline Sn & $\mathrm{N}$ & $\mathbf{N}$ & $\mathrm{N}$ & $\mathrm{N}$ \\
\hline $\mathrm{Ti}$ & 0.002 & 0.012 & 0.002 & $\mathbf{N}$ \\
\hline v & $\mathrm{N}$ & N & N & $\mathrm{N}$ \\
\hline $2 \pi$ & $\mathbf{N}$ & 0.011 & N & $\mathbf{N}$ \\
\hline
\end{tabular}




\section{Table 4 (Continued)}

\section{Elements}

A1

$\mathrm{Ca}$

$\mathrm{Cr}_{\mathrm{r}}$

$\mathrm{Cu}$

$\mathrm{Fe}$

$\mathrm{Mg}$

$\mathrm{Mn}$

Mo

$\mathrm{Na}$

$\mathrm{Ni}$

$P$

$\mathrm{Pb}$

$\mathrm{Su}_{\mathrm{U}}$

$\mathrm{Ti}$

$\mathrm{V}$

$\mathrm{Zn}$
Laborer

Quarry

0.150

0.178

$\mathrm{N}$

$\mathrm{N}$

0.008

0.003

$\mathrm{N}$

$\mathrm{N}$

0.015

$\mathrm{N}$

$\mathrm{N}$

$\mathrm{N}$

N

N

$\mathrm{N}$

$\mathrm{N}$
Laborer

Riln Plant \# 2

$$
\begin{aligned}
& 0.097 \\
& 1.896 \\
& N \\
& 0.003 \\
& 0.153 \\
& 0.031 \\
& N \\
& 0.007 \\
& 0.008 \\
& N \\
& 0.007 \\
& 0.008 \\
& N \\
& 0.004 \\
& N \\
& 0 .
\end{aligned}
$$$$
\text { . } 0.004
$$

$-\mathrm{N}$ 
TABLE 5

AREA RESPIRABLE DUST AND QUARTZ CONCENTRATIONS

REPORTED IN MILLIGRAMS PER CUBIC METER (mg/m ${ }^{3}$ )

IDEAL CEMENT - FLORENCE, COLORADO

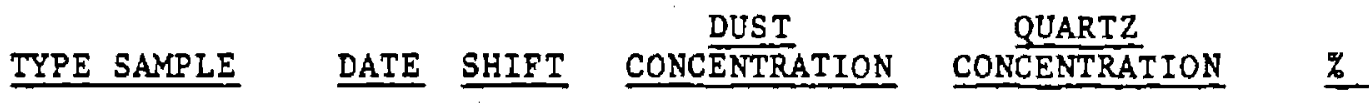

PACKHOUSE

Respirable

High Vol Resp

Mar 221

0.95

0.85

High Vol Resp

1.87

$\mathrm{N}$
$\mathrm{N}$
0.01

$-$

$-$

MILL RM PLANI

Respirable

High Vol Resp

High Vol Resp

Mar 231

1.26

0.90

2.45

$\mathrm{N}$

0.02

$-$

8.32

0.05

0.6

Tota 1

0.05

0.6 


PERCENTAGE

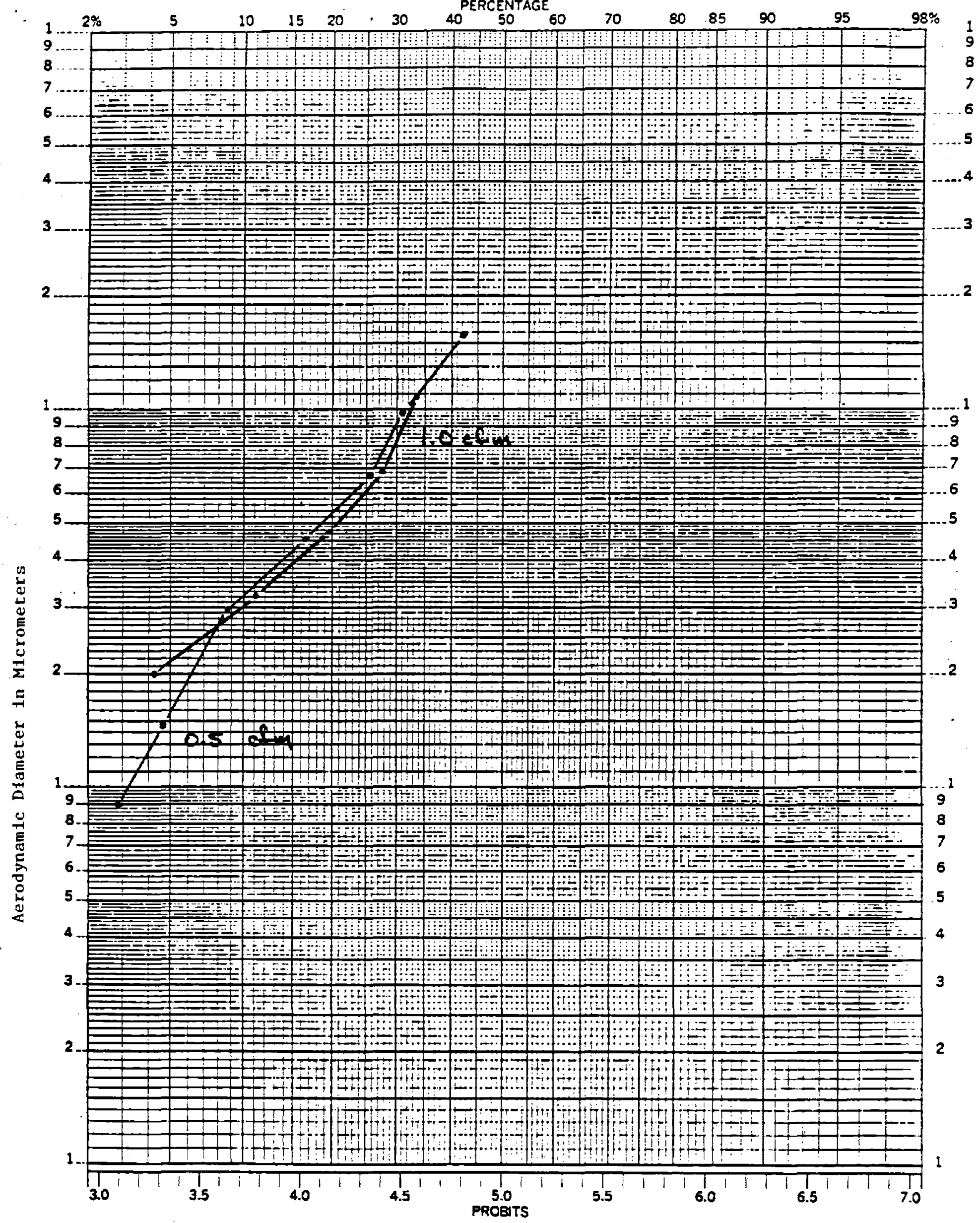

Percentage of Particle Mass Less Than Corresponding Diameter 


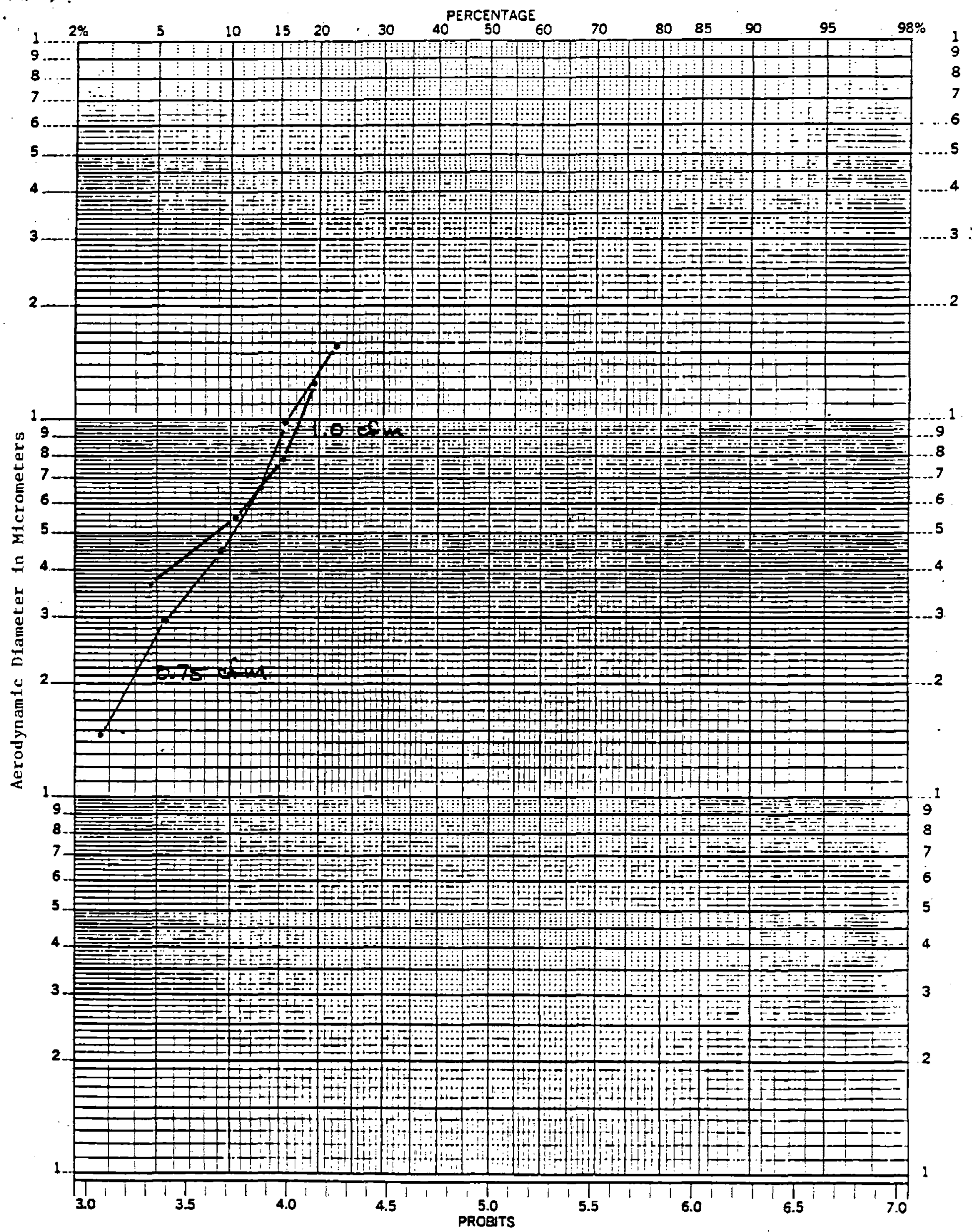

Percentage of Particulate Mass Less Than Corresponding Dlameter 


\section{ANALYSIS OF BULK MATERIAL PRESENTED AS PERCENT BY WEIGHT IDEAL CEMENT - FLORENCE, COLORADO}

AREA

$1^{0} \mathrm{Crusher}$

$2^{0}$ Crusher

Type 1

Cement

Masonry

Cement

Type 3

Cement

Type IA

Cement

Type 2

Cement

Clinker

Plant 3

Mill Rafters

Plant 3

Beneath

Precipitation

Feed end of

Riln-Plant 3

Mill Rm

Dust Plant 2

C1 inker

Cooler

Plant 2

Waste Dust

Feed End

Plant 2

\section{QUARTZ}

CRISTB

AL $\underline{C R} \quad \underline{C O}$

$\underline{M C}$

8.3

8.6

N

$$
4.5
$$

N

N

N

N

4.6

6.8

N

Not

Analyzed

4.4

$\begin{array}{ll}1.7 & \mathrm{~N} \\ 2.0 & \mathrm{~N} \\ 2.5 & \mathrm{~N}\end{array}$

$\mathbf{N}$
$\mathbf{N}$
$\mathrm{N}$

N

N

$2.9 \mathrm{~N} N$

$2.3 \mathrm{~N}, \mathrm{~N}$

$2.5 \mathrm{~N} N$

$2.0 \mathrm{~N} N$

$2.1 \mathrm{~N} N$

N

$2.0 \mathrm{~N}$

N.

N

$2.0 \mathrm{~N} N$

$1.8 \mathrm{~N}$

N

Ana -

lyzed

N
$0.60 \cdot 0.08 \mathrm{~N}$

$0.520 .08 \mathrm{~N}$

$0.710 .15 \mathrm{~N}$

$0.580 .14 \mathrm{~N} \quad \mathrm{~N}$

$0.630 .13 \mathrm{~N} \quad \mathrm{~N}$

$0.680 .15 \mathrm{~N}$

0.003

$\begin{array}{llll}2.0 \mathrm{~N} & 0.520 .13 \mathrm{~N} & 0.003\end{array}$

$0.550 .12 \mathrm{~N}$

0.005

$0.620 .12 \mathrm{~N}$

0.003

$0.520 .13 \mathrm{~N} N$

$0.520 .13 \mathrm{~N} \quad \mathrm{~N}$

$0.570 .13 N \quad \mathrm{~N}$

$\begin{array}{llllll}2.0 & \mathrm{~N} & \mathrm{~N} & 0.46 & 0.12 \mathrm{~N} & \mathrm{~N}\end{array}$

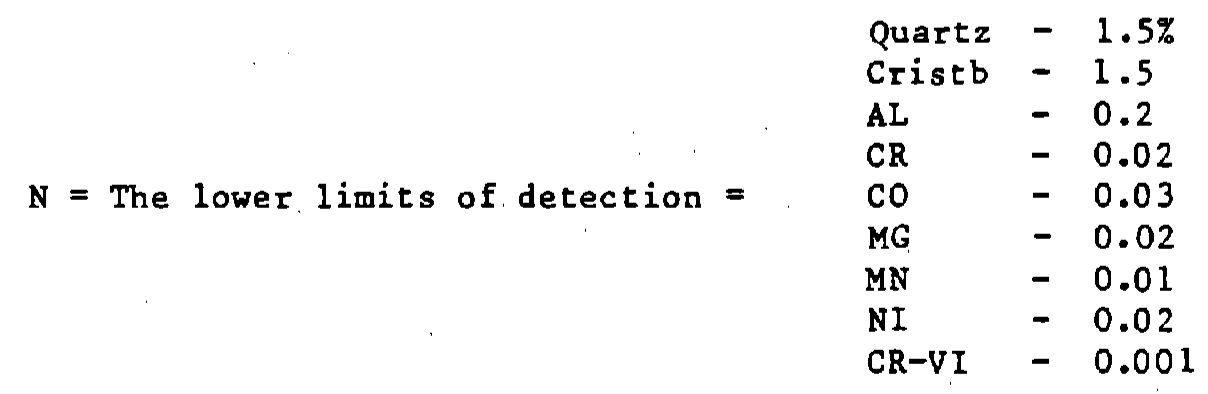


TABLE 7

HYDROGEN ION CONCENTRATION ( $\mathrm{pH}$ ) OE BULK SAMPLES

IDEAL CEMENT - FLORENCE, COLORADO

DUST

Type I

Cement

Masonary

Cement

Clinker

(Plant 2)

Kiln Waste

Dust (Plant 2)

Raw Material

Primary Crusher
PARTICLE SIZE CUTPOINT

$<20 \mathrm{Hm}$

$<20 \mu \mathrm{m}$

$<30 . \mu \mathrm{m}$

$<20 \mu m$

$<20 \mathrm{Hm}$
pH

11.3

11.2

11.9

11.5

10.0 
TABLE 8

PERSONAL DOSIMETER ANALYSIS FOR NITROGEN DIOXIDE

REPORTED IN PARTS PER MILLION - PPM

IDEAL CEMENT - FLORENCE, COLORADO

\begin{tabular}{|c|c|c|c|c|}
\hline JOB & AREA & DATE & SHIFT & CONCENTRATION-pPM \\
\hline Laborer & $\begin{array}{l}\text { Mill Rm } \\
\text { Plant } 3\end{array}$ & March 22 & 1 & 0.09 \\
\hline La borer & $\begin{array}{l}\text { Mill Rm } \\
\text { Plant } 3\end{array}$ & & & 0.04 \\
\hline Laborer & $\begin{array}{l}\text { Front End Kiln } \\
\text { Plant } 3\end{array}$ & & & 0.10 \\
\hline Maintenance & $\begin{array}{l}\text { Plant Wide } \\
\text { Plant } 3\end{array}$ & & & 0.13 \\
\hline $\begin{array}{l}\text { Driller } \\
\text { Crusher }\end{array}$ & $\begin{array}{l}\text { Quarry } \\
10 \text { Crusher }\end{array}$ & & & $\begin{array}{l}0.12 \\
0.18\end{array}$ \\
\hline $\begin{array}{l}\text { Operator } \\
\text { Shift }\end{array}$ & $\begin{array}{l}\text { Quarry } \\
\text { Plant Wide }\end{array}$ & & & 0.10 \\
\hline $\begin{array}{l}\text { Repair } \\
\text { Sack Loader }\end{array}$ & $\begin{array}{l}\text { Plant } 3 \\
\text { Packhouse }\end{array}$ & & & 0.06 \\
\hline Bagger & Packhouse & & & 0.12 \\
\hline $\begin{array}{l}\text { Bagger } \\
\text { Truck Driver } \\
\text { Driller }\end{array}$ & $\begin{array}{l}\text { Packhouse } \\
\text { Quarry } \\
\text { Quarry }\end{array}$ & Mar 23 & $1-$ & $\begin{array}{l}0.09 \\
0.07 \\
0.17\end{array}$ \\
\hline Repairman & $\begin{array}{l}\text { Mill Rm } \\
\text { Plant } 2\end{array}$ & & & 0.06 \\
\hline Repairman & $\begin{array}{l}\text { Plantwide } \\
\text { Plant } 2\end{array}$ & & & 0.06 \\
\hline Kiln Laborer. & $\begin{array}{l}\text { Front End kiln } \\
\text { Plant } 2\end{array}$ & & & 0.10 \\
\hline $\begin{array}{l}\text { Laborer } \\
\text { Crane Oper } \\
\text { Bobcat Oper } \\
\text { Painter }\end{array}$ & $\begin{array}{l}\text { Roof - Plant } 2 \\
\text { Crane - Plant } 2 \\
\text { Plantwide } \\
\text { Mill RI-Plant } 2\end{array}$ & 2 & & $\begin{array}{l}0.07 \\
0.02 \\
0.02 \\
\mathrm{~N}\end{array}$ \\
\hline
\end{tabular}

$\mathrm{N}=$ below the analytical limit of detection ( $0.02 \mathrm{ppm})$

mean $=0.08 \mathrm{ppm}$

$\mathrm{sd}=.05$

range $=.01-.18 \mathrm{pPm}$ 
TABLE 9 DIRECT READING ANALYSIS FOR CARBON MONOXIDE
REPORTED IN PARTS PER MILLION - PPM

IDEAL CEMENT - FLORENCE, COLORADO

March 23, 1982

AREA

Aisle of Packhouse Across from office

By workers placing bags on pallet (Door open)
LOCATION OF FORKLIFT

Bagging Area

Backing from bagging area past office

Out on loading dock

Backing past office after placing pallet on truck

Out on loading dock

Lift idling in area wāiting to remove loaded pallet
READING

45-60

85

6

100

0

8 
TABLE 10

\section{RESULTS OF COMMUNITY DRINKING WATER ANALYSIS BY COLORADO DEPARTMENT OF HEALTH \\ IDEAL CEMENT - FLORENCE, COLORADO}

\begin{tabular}{|c|c|c|c|}
\hline SUBSTANCE & CONCENTRATIONS & $\underline{\text { LLD }}$ & MANDATORY GUIDELINES \\
\hline \multicolumn{4}{|l|}{ Elements } \\
\hline$\overline{\text { Arsenic }}$ & N & $0.01 \mathrm{mg} / \mathrm{l}$ & $0.05 \mathrm{mg} / \mathrm{l}$ \\
\hline Barium & $\mathrm{N}$ & 0.5 & 1.0 \\
\hline Cadmium & N & 0.0003 & 0.01 \\
\hline Chromium & $\mathrm{N}$ & 0.005 & 0.05 \\
\hline F1uoride & 0.64 & 0.1 & 2.4 \\
\hline Lead & $\mathbf{N}$ & 0.005 & 0.05 \\
\hline Mercury & $\mathbf{N}$ & 0.0005 & 0.002 \\
\hline Nitrates & $\mathbf{N}$ & 0.5 & 10.0 \\
\hline Selenium & N & 0.002 & 0.01 \\
\hline Silver & $\mathbf{N}$ & 0.05 & 0.05 \\
\hline \multicolumn{4}{|l|}{ Pesticides } \\
\hline Lindane & N & 0.000007 & 0.004 \\
\hline Eudrin & $\mathbf{N}$ & 0.00006 & 0.0002 \\
\hline Methoxychlor & $\mathbf{N}$ & 0.00018 & 0.1 \\
\hline Toxaphene & $\mathbf{N}$ & 0.00067 & 0.005 \\
\hline \multicolumn{4}{|l|}{ Herbicides } \\
\hline$\overline{2,4-D}$ & $\mathbf{N}$ & 0.00038 & 0.1 \\
\hline $2,4,5-T P$ & $\mathbf{N}$ & 0.00012 & 0.01 \\
\hline
\end{tabular}

